\title{
Pengaruh Informasi Kadar Gula Darah Terkini dan Probabilitas Terjangkitnya Diabetes Mellitus terhadap Belief Updating dan Willingness to Pay Premi Asuransi Kesehatan
}

\author{
Restiatun* \\ Universitas Tanjungpura
}

\begin{abstract}
This research evaluates effect of the current information about blood glucose level based on medical test to the value of the premium willingness to pay (WTP) and ownership of health insurance. The data collecting methodology in this study used laboratory experiments. Participants involved in this research is limited only to the individual that has been aged a minimum of thirty-five years and have a permanent income. The sample selection was based on the fact that the individuals in that age have increasing tencendy in the prevalence of the risk contracting acute diseases, such diabetes mellitus. While the terms on permanent-income based on the consideration that only income individuals who can afford to buy health insurance.The results of this study show that blood glucose current information significantly influence subjective belief of health status which in turn affects the value of WTP and decisions of individuals in health insurancepossession. Other variables that significantly affect the individual health risk perceived are the number of sick days in a month. Other significant variable is income. While the ownership of health insurance is significantly only influenced by subjective health status, after receiving the objective information based on blood glucose level medical report.
\end{abstract}

Keywords: subjective belief on health status, blood glucose, willingness to pay, health insurance

\section{PENDAHULUAN}

Jumlah penderita diabetes mellitus (DM) di Indonesia sepanjang waktu semakin meningkat. Menurut data WHO, tahun 2006 jumlah penderita diabetes di Indonesia mencapai 14 juta orang dan jumlah ini menempati urutan ke-4 terbesar di dunia. Peningkatan jumlah penderita diabetes mellitus ini tidak terlepas adanya keyakinan (priorbelief) yang salah yang berkembang dalam masyarakat bahwa diabetes millitus merupakan penyakit orang tua ${ }^{1}$ atau penyakit keturunan.Keyakinan tersebut memang tidak sepenuhnya salah.Faktor keturunan memiliki pengaruh terhadap besarnya risiko

\footnotetext{
* Korespondensi: Restiatun, Jurusan Ilmu Ekonomi, Fakultas Ekonomi, Universitas Tanjungpura, Jalan Prof. Dr. H. Hadari Nawawi, Pontianak, Indonesia. Email: hariestya@yahoo.com

${ }^{1}$ Orang yang berusia 40 tahun ke atas memiliki risiko tinggi menderita Diabetes Mellitus, terlebih bagi yang mengalami obesitas dan kurang gerak (www.infosehat.com)
} 
seorang individu dapat terjangkit diabetes mellitus.Tetapi selain keturunan, pola hidup juga berperan besar dalam penentuan prevalensi penyakit ini.

Keyakinan seseorang sangat mempengaruhi cerapan risiko terhadap suatu penyakit dan selanjutnya akan menentukan willingness to paypremi asuransi kesehatan, dimananilai willingness to pay ini mengukur manfaat atas asuransi kesehatan yang akan diterima oleh individu/rumah tangga. Untuk mengetahui secara akurat probabilitas untuk mengidap penyakit diabetes mellitus dapat dilakukan dengan pemeriksaan kadar gula darahnya. Probabilitas individu untuk terjangkit diabetes mellitus ditentukan oleh pola hidup, faktor keturunan, jenis kelamin, dan usia. Dari seluruh faktor di atas, pola hidup merupakan satu-satunya faktor yang dapat dikendalikan.

Seorang individu seringkali merasa bahwa dirinya telah berpola hidup sehat dan tidak memiliki faktor keturunan, dan tanpa informasi objektif yang akurat mengenai kadar gula darah, sehingga mereka meyakini bahwa dirinya tidak berisiko atau memiliki probabilitas yang kecil untuk menderita diabetes mellitus.Prior beliefyang dibangun tanpa berdasarkan rambu-rambu dari fakta objektif menyebabkan individu mengalami cognitive dissonance ${ }^{2}$.Prior belief ini akan menentukan besarnya manfaat dari asuransi kesehatan yang tercermin dari besarnya nilai willingness to pay mereka dan selanjutnya akan mempengaruhi keputusan dalam berasuransi kesehatan.

Pemberian informasi objektif yang akurat, mungkin direspon oleh individu dengan mengupdate keyakinannya, atau dengan kata lain melakukan belief updating, selanjutnyaindividu akan memiliki keyakinan baru atas status kesehatannya (posterior belief). Posterior belief ini akan diikuti dengan perubahan nilaiwillingness to payatas premi asuransi. Singkatnya,keyakinan akan menentukan willingness to pay individu atas premi dan keputusan dalam berasuransi kesehatan. Secara umum, seorang individu/rumah tanggaakan bersedia membayar harga suatu barang atau jasa jika manfaat yang akan diterima dari barang atau jasa tersebut lebih besar dari atau sama dengan willingness to pay mereka.

\section{KERANGKA TEORITIS}

Ketika seorang individu merasa telah berperilaku sehat dan tidak memiliki faktor keturunan maka sangat mungkin hal ini akan menumbuhkan keyakinan subjektif bagi individu bahwa dirinya memiliki status kesehatan yang baik dalam jangka panjang. Pembentukan keyakinan subjektif (prior belief) tanpa pencarian informasi objektif ini sering menyebabkan individu mengalami kesalahan dalam mencerap risiko terkait dengan status kesehatan dan probabilitas terjangkinyat penyakit, khususnya penyekit akut seperti diabetes mellitus.Adanya keterbatasan memori manusia dan keterbatasan kapasitas dalam memproses informasi yang diterima, seringkali menyebabkan

\footnotetext{
${ }^{2}$ Cognitive dissonance adalah ketidaksesuaian individu atas sikap dan perilaku mereka (Drycott dan
} Dubb, 1994). 
probabilitas subjektif ini menjadi kurang bisa dikalibrasikan atau secara internal tidak konsisten dan bias (Kahneman et al., 1982; Gilovich et al., 2002; Fox dan Clemen, 2005).

Probabilitas subjektif dapat dibangun sejalan dengan fungsi utilitas ekspektasi dibangun. Diasumsikan $\mathrm{p}(\mathrm{H})$ merupakan suatu probabilitas subyektif individual bahwa hipotesis tertentu adalah benar, dan $\mathrm{E}$ adalah kejadian yang memberikan bukti bahwa $\mathrm{H}$ benar. Dari keberadaan $\mathrm{p}(\mathrm{H})$ dan $\mathrm{E}$, tentu saja akan memunculkan pertanyaan tentang bagaimana seharusnya agen ekonomi yang rasional menyesuaikan probabilitas keyakinannya mengenai $\mathrm{H}$ berdasarkan rambu-rambu dari bukti E. Secara matematis joint probabilitas dari $\mathrm{E}$ yang terobservasi dan $\mathrm{H}$ yang menjadi kenyataan sebagai berikut:

$\mathrm{p}(\mathrm{H}, \mathrm{E})=\mathrm{p}(\mathrm{H} \mid \mathrm{E}) \mathrm{p}(\mathrm{E})=\mathrm{p}(\mathrm{E} \mid \mathrm{H}) \mathrm{p}(\mathrm{H})$

dengan merangkai kembali sisi kanan persamaan di atas

$\mathrm{p}(\mathrm{H} \mid \mathrm{E})=\frac{p(E \mid H) p(H)}{p(E)}$

persamaan di atas merupakan bentuk dari Bayes's Law yang menghubungkan prior probability $\mathrm{p}(\mathrm{H})$, probabilitas bahwa hipotesis benar sebelum ada bukti yang terobservasi, dengan posterior probability, probabilitas bahwa hipotesis benar setelah terdapat bukti yang terobservasi (Manski, 1981).

Bayes's Law mengikuti secara langsung manipulasi sederhana atas probabilitas conditional.Jika perilaku individu memenuhi restriksi yang mencukupi untuk memastikan keberadaan probabilitas subjektif, maka probabilitas tersebut seharusnya juga memenuhi Bayes's Law.Bayes's Law ini penting, karena hal ini menunjukkan bagaimana seorang individu yang rasional seharusnya meng-update probabilitas subjektifnya berdasarkan rambu-rambu dari bukti, dan selanjutnya menyediakan dasar bagi model perilaku pembelajaran yang rasional (rational learning behavior).Baik fungsi utilitas maupun probabilitas subjektif dapat direkonstruksi dari perilaku pilihan yang terobservasi, sepanjang perilaku pilihan yang terobservasi mengikuti aksiomaaksioma tertentu yang secara intuitif masuk akal.Tetapi menurut Varian (1992, p.192), meskipun kelihatannya aksioma-aksioma yang digunakan tersebut secara intuitif masuk akal, tetapi hal ini tidak selalu merupakan deskripsi yang akurat bagaimana individu secara aktual berperilaku.Diperlukan bukti empiris untuk menentukan kedua hal tersebut.

Salah satu informasi objektif yang akurat untuk menunjukkan kondisi terkini status kesehatan individu dapat diperoleh melalui pemeriksaan kesehatan. Pemeriksaan kadar gula darah akan menentukan besarnya probabilitas terjangkit penyakit diabetes mellitus, di samping juga dipengaruhi oleh jenis kelamin dan usia. Tetapi kenyataannya sebagian individu tidak bersedia melakukan pemeriksaan kadar gula darah secara sukarela, meskipun mereka mengetahui informasi yang didapatkan dari pemeriksaan ini 
sangat berguna bagi kehidupannya (lihat Magat, Viscussi dan Huber, 1987; Camerer dan Kunreuther, 1989).Keengganan ini mungkin disebabkan oleh besarnya biaya untuk mendapatkan informasi atau perasaan cemas yang dirasakan individu ketika mereka harus melakukan belief updating setelah mengetahui bahwa dirinya memiliki probabilitas tinggi untuk sakit, ataupun disebabkan terjadinya mental accounting dimana individu lebih memperhatikan perilaku yang mempengaruhi penampilan fisiknya dibanding perilaku yang mempengaruhi status kesehatannya (Steleffson, Wang dan Klein, 2006).

Informasi tentang probabilitas terjangkitnya diabetes mellitus dapat digunakan untuk menyusun sebuah manajemen risiko untuk menghindari kehilangan kekayaan (losses) yang diakibatkan terjangkit penyakit.Individu yang risk averse membuat sebuah rencana avoiding risk, misalnya dengan membeli premi asuransi kesehatan. Mereka membayar premiumex-ante dan menerima reimbursement ketika terjadi risiko terjangkit.

Secara umum, individu akan membeli barang atau jasa ketika harga barang atau jasa tersebut lebih besar atau sama dengan harganya. Manfaat tersebut lebih bersifat subjektif dan akan tercermin dari nilai willingnessto pay individu atas barang atau jasa tersebut. Manfaat dari asuransi kesehatan sangat ditentukan oleh keyakinan subjektif individu atas status kesehatannya. Semakin tidak baik status kesehatan yang diyakininya akan meningkatkan manfaat subjektif atas asuransi kesehatan. Ketika keyakinan subjektif individu dibangun berdasarkan informasi objektif, maka individu dapat menentukan secara lebih tepat cerapan risiko untuk terjangkit penyakit sehingga dapat menghitung manfaat dari asuransi kesehatan dan mengambil keputusan yang tepat dalam hal berasuransi kesehatan.

Ketika individu memilih asuransi kesehatan dari beberapa alternatif kontrak, mereka melihat informasi tentang sifat umum dari preferensi penghindaran risiko (avoiding risk) (Friedman, 1974).Penelitian yang dilakukan oleh Barsky et al. (1997) dan Machnes (2006) menunjukkan bahwa preferensi risiko mempengaruhi kepemilikan asuransi kesehatan. Individu yang risk averse mungkin akan belajar dari pengalaman generasi sebelumnya ${ }^{3}$.

\section{METODOLOGI PENELITIAN}

Penelitian ini menggunakan metode eksperimen lab. Pemilihan metode didasarkan pada pertimbangan beberapa penelitian terdahulu tentang kepemilikan asuransi kesehatan menggunakan kuesioner survey (Kerssens dan Groenewegen, 2005; Saver dan Doescher, 2000; Barsky etal., 1997), dimana metode keusioner survey

\footnotetext{
${ }^{3}$ Learning Theory diturunkan dari dua sumber utama, yaitu Stimulus Respons Theory dan Cognitive Theory. Berdasarkan Stimulus Respon Theory, pembelajaran yang dihasilkan dari kerugian akan mengurangi dorongan psikologi yang mengaktivasi perilaku sehingga frekuensi perilaku akan ditentukan oleh konsekuensinya. Sedangkan Cognitive Theory lebih menekankan peran hipotesis atau ekspektasi subjektif yang diyakini (Rosenstock, Strecher dan Becker, 1988).
} 
memiliki kemungkinan bias yang disebabkan partisipan kurang mencerap risiko yang dihadapinya. Dalam metode kusioner survey tidak ada payoff yang mengikat setiap keputusan partisipan, sementara keputusan untuk berasuransi kesehatan sangat erat kaitannya dengan kondisi ketidakpastian. Hal ini akan lebih tepat jika riset tentang asuransi menggunakan metode eksperimen lab.

Eksperimen lab ini melibatkan 100 orang, dengan 50 orang termasuk dalam kelompok tritmen dan 50 sisanya termasuk dalam kelompok kontrol. Kelompok kontrol dalam riset ini digunakan untuk melihat apakah perubahan keyakinan subjektif ndividu atas status kesehatannya benar-benar disebabkan oleh tritmen berupa pemeriksaan kadar gula darah, yang berikutnya akan menyebabkan perubahan pada nilai willingness to pay premi asuransi kesehatan dan keputusan dalam berasuransi kesehatan.

Partisipan dalam riset ini adalah mahasiswa S2, S3 dan alumni di lingkungan kampus UGM. Pemilihan partisipan seperti di atas mengacu pada pernyataan Karder (1996) bahwa suatu riset eksperimen akan memberikan hasil maksimal ketika partisipan yang terlibat dalam eksperimen mendekati fenomena yang sebenarnya. Partisipan yang terdiri atas civitas akademika yang meliputi mahasiswa S2, S3 serta alumni tersebut diharapkan memiliki karakteristik yang mendekati fenomena realita sebenarnya karena rata-rata partisipan berusia di atas $35^{4}$ tahun dan telah memiliki penghasilan, sementara itu mulai usia 35 tahun terdapat beberapa individu yang mulai terjangkit penyakitpenyakit akut serta hanya individu yang telah berpenghasilan yang mampu membeli asuransi kesehatan. di samping itu, pemilihan partisipan tersebut juga didasarkan pada asumsi bahwa seluruh partisipan memiliki nilai yang sama terhadap status kesehatannya.

Rekruitmen partisipan dilakukan denganpooled, yakni partisipan yang dilibatkan dalam eksperimen akan dipilih secara random dari seluruh pendaftar yang ada. Pemilihan secara random dilakukan dengan membuat lintingan kertas yang berisi nomer urutan pendaftaran partisipan dan kemudian diambil secara random untuk mendapatkan lima puluh partisipan untuk kelompoktritmen dan lima puluh partisipan untuk kelompok kontrol. Hal ini dilakukan untuk menghindari terjadinya self selecting bias.Di samping itu, pooled partisipan ini dilakukan juga agar hasil dari eksperimen ini dapat digeneralisasi.

Tata cara eksperimen ini menggunakan computer yang telah sebelumnya diisi dengan program yang didesain secara khusus sesuai dengan tujuan penelitian ini. Adapun dalam eksperimen ini setiap partisipan akan menerima uang kehadiran sebesar Rp. 50.000,00 dan endowment sebanyak tiga voucher dimana setiap voucher bernilai Rp.

\footnotetext{
${ }^{4}$ Menurut penelitian epidemiologi yang dilakukan Linska (2007), stroke usia muda adalah kurang dari 45 tahun. Penelitian ini merupakan penelitian kasus kontrol, sebagai kasus adalah 214 pasien (berusia 15-45 tahun) dengan stroke iskemik akut yang pertama.Penelitian ini mengkaitkan komponen sindroma metabolik dengan risiko stroke. Komponen sindroma metabolik yang dapat teramati dalam catatan medik adalah sebagai berikut: peningkatan trigliserida (> $150 \mathrm{mg} / \mathrm{dl}$ ), penurunan kolesterol HDL (dibawah $40 \mathrm{mg} / \mathrm{dl}$ ), peningkatan tekanan darah (diatas $130 \mathrm{mmHg}$ untuk sistolik atau diatas $85 \mathrm{mmHg}$ untuk diastolik), dan peningkatan kadar gula puasa diatas $100 \mathrm{mg} / \mathrm{dl}$.
} 
50.000,00. Mata uang yang digunakan dalam eksperimen ini adalah Eksperimen Rupiah $(\varepsilon)$.Sedangkan untuk kurs yang digunakan adalah Rp.1, 00 bernilai $\varepsilon 100$, sehingga setiap partisipan memiliki endowment sebesar $\varepsilon 15.000 .000$. Untuk penyakit diabetesmellitus dan komplikasi yang disebabkan tingginya kadar gula darah membutuhkan biaya perawatan sebesar $\varepsilon 5.000 .000$.

Institusi dalam eksperimen ini didesain sedemikian rupa, sehingga komposisi endowment dan payoff mampu menjelaskan hubungan sebab akibat antara variabel terikat dan variabel penjelas. Setiap keputusan partisipan akan berakibat pada endowment yang dimilikinya. Setiap keputusan yang kurang tepat akan menyebabkan losses (kerugian) dan akan berdampak pada total reward yang akan diterima di akhir periode eksperimen. Sebagaimana yang dinyatakan oleh Friedman dan Sunder (1994) bahwa jika ketiga syarat berikut dapat dipenuhi, maka eksperimenter dapat mengontrol dengan baik karakteristik subjek penelitian, sehingga eksperimenter lebih dapat mengontrol efek variabel pengganggu di luar variabel penelitian. Syarat-syarat tersebut adalah non-satiation: subjek lebih menyukai reward (bayaran dari eksperimen) yang banyak dibanding dengan yang sedikit (more is preferred to less), dan tidak satiated; Saliency: besarnya reward yang diterima subjek tergantung pada pengambilan keputusan atau tindakan subjek tersebut dalam eksperimen (dan tindakan subjek lain) seperti yang diatur oleh aturan kelembagaan dalam eksperimen tersebut; dan reward dominance: perubahan utilitas subjek dalam eksperimen didominasi oleh reward, sementara itu hal-hal lain yang dapat mempengaruhi utilitas subjek dapat diabaikan. Misalnya V (m, z) adalah preferensi subyek terhadap reward $(\mathrm{m})$ dan hal-hal lain $(\mathrm{z})$; dominasi reward menjadi lebih persuasif bila reward salien $(\Delta \mathrm{m})$ meningkat dan bila komponen z dijaga konstan.

Jalannya eksperimen untuk kelompok tritment ini secara lengkap adalah sebagai berikut.

Tahap 1: Metode penentuan nilai WTP premi asuransi kesehatan mula-mula dilakukan dengan bidding, dimana bidding ini dilakukan dengan posted offer (metode eksekusi: take it or leave it). Para partisipan menghadapi pertanyaan apakah mereka bersedia membayar nominal tertentu untuk premi asuransi kesehatan yang meng-cover $100 \%$ biaya perawatan kesehatan yang akan mereka beli, kemudian nilai tersebut akan terus dinaikkan sampai tidak ada seorang partisipan yang bersedia membayarnya. Setelah itu partisipan menghadapi pertanyaan dalam bentuk open-ended berupa pertanyaan berapa sesungguhnya nilai WTP mereka atas premi asuransi kesehatan.Setiap nilai yang di-bid oleh partisipan berarti mereka telah membeli premi seharga nilai tersebut.

Tahap 2: Pada tahap ini dilakukan pemeriksaan kondisi kesehatan para partisipan dengan pemeriksaan tekanan darah dan pengambilan darah untuk mengetahui kadar kolesterol dan kadar gula dalam darah. Hasil pemeriksaan medis ini selanjutnya akan diinformasikan kepada para partisipan. Di samping informasi 
mengenai kondisi kesehatan terkini mereka, partisipan juga menerima informasi tentang ambang batas sehat kadar gula dalam darah serta probabilitas lima sampai sepuluh tahun mendatang terjangkitnya diabetes mellitus sesuai dengan hasil pemeriksaan kesehatan.

Tahap 3: Pada tahap ini para partisipan menghadapi kembali komputernya masingmasing untuk segera melaksanakan tugasnya. Skenario yang disusun pada tahap ini ditujukan untuk mengamati apakah para partisipan melakukan beliefupdating atas status kesehatan mereka yang akan terlihat dari perubahan keyakinan dan nilai bidding atas WTP premi asuransi kesehatan mereka. Ketika partisipan tidak meng-update keyakinan mereka, artinya mereka tidak melakukan belief updating. Seperti pada tahap sebelumnya, apabila pada tahap ini keyakinan para partisipan tidak sesuai dengan probabilitas objektif status kesehatannya, maka voucher yang dimiliki oleh partisipan akan kembali dikurangi. Untuk mengetahui apakah partisipan melakukan belief updating atau tidak, partisipan akan menghadapi pertanyaan tentang status kesehatan mereka. Jawaban ini kemudian akan dibandingkan dengan jawaban atas pertanyaan yang sama yang diberikan dalam kuesioner sebelum eksperimen dilaksanakan.

Tahap 4: Pada tahap ini setiap partisipan akan menjalani proses randomisasi terjadinya penyakit berdasarkan probabilitas masing-masing partisipan sesuai dengan hasil pemeriksaan kesehatan. Randomisasi dilakukan dengan cara mengambil lintingan kertas yang berisi angka satu sampai dengan seratus, di mana beberapa angka pertama (sesuai dengan probabilitas terjadinya penyakit) menunjukkan terjadinya penyakit diabetes mellitus. Ketika partisipan terkena penyakit sebagai hasil randomisasi maka mereka akan mengeluarkan biaya perawatan sebesar $\varepsilon 5.000 .000$. Jika partisipan mengambil keputusan untuk berasuransi maka seluruh biaya perawatan kesehatan yang dikeluarkannya akan dicover oleh perusahaan asuransi, tetapi jika tidak membeli premi premi asuransi maka partisipan harus menanggung sendiri seluruh biaya perawatan kesehatannya maka endowment-nya akan habis.

Di akhir periode, voucher yang dimiliki oleh para partisipan akan ditukarkan dengan sejumlah uang yang sesuai dengan kurs yang telah ditetapkan di awal periode eksperimen.Jadi di akhir periode, setiap partisipan maksimum akan menerima uang Rp200.000, 00 dikurangi harga pembelian premi asuransi kesehatan dan minimum Rp50.000,00 ketika partisipan melakukan dua kali kesalahan dan menderita penyakit diabetes mellitus. Secara grafis proses pengambilan keputusan partisipan untuk treatmentgroup dapat digambarkan seperti Gambar 1.

Adapun untuk kelompok kontrol, tahap-tahap yang dilaksanakan sama dengan tahap-tahap pada kelompoktritmen, kecuali pada tahap 2. Pada tahap 2 ini, partisipan menerima refreshment saja, tidak dilakukan pemeriksaan kesehatan seperti halnya yang 
dilakukan pada kelompok tritmen. Skenario ini dilakukan untuk melihat apakah jika terjadi perubahan nilai WTP pada kelompok tritmen benar-benar disebabkan oleh adanya pemeriksaan gula darah, bukan sebab lain. Atau dengan kata lain, adanya kelompok kontrol ini ditujukan untuk melihat efektivitas tritmenyang diberikan dalam eksperimen. Berikutnya partisipan dalam kelompok kontrolakan menjalani randomisasi guna mendapatkan probabilitas terjadinya sakit dengan menggunakan probabilitas berdasarkan NCEP3ATP. Hasil ini yang kemudian akan digunakan untuk melakukan randomisasi terjadinya penyakit. Untuk kelompok kontrol, ketika hasil random seorang partisipan menderita penyakit diabetes mellitus, maka voucher yang dimiliki akan berkurang satu sebagai gambaran bahwa sakit menyebabkan disutility. Hal ini juga dilakukan agar ganjaran yang diterima baik oleh kelompok kontrol maupun kelompok tritmen sama besar. Skenario ini ditujukan untuk menguji saliansi ganjaran eksperimen.

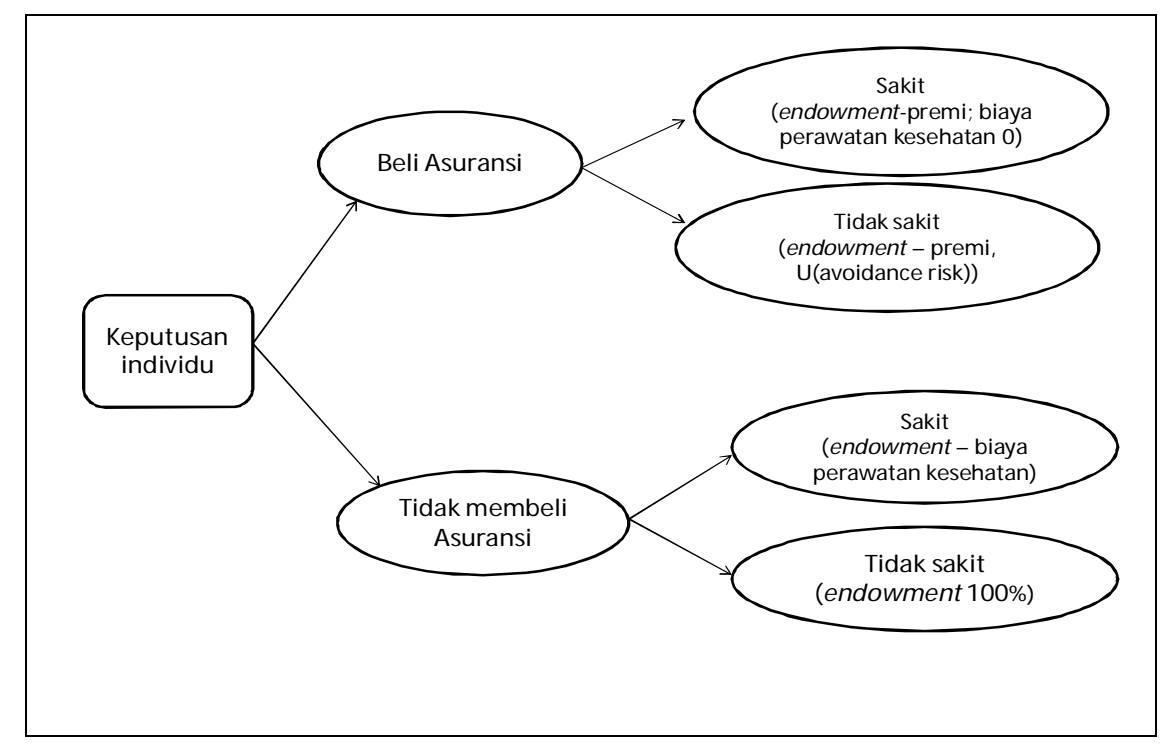

Gambar 1. Gambar Decision Tree Pembelian Asuransi Kesehatan

\section{MODEL ESTIMASI}

Untuk mengestimasi hubungan antar variabel yang diuji serta pengujian hipotesis dalam penelitian ini digunakan regresi model probit. Adapun secara matematis model tersebut dapat ditulis seperti di bawah ini.

\subsection{Sebelum ada informasi kondisi kesehatan terkini}

Mengacu model WTP yang digunakan dalam beberapa penelitian sebelumnya (Pavlova, Groot dan Merode, 2004; Olsen, Donalson dan Pereira, 2004; serta Awad, et. al, 2004) bahwa WTP $=\alpha_{0}+\beta_{\mathrm{i}} \mathrm{x}_{\mathrm{h}}+\mathrm{z}_{\mathrm{i}}$, dimana $\mathrm{x}_{\mathrm{h}}$ adalah karakter individual termasuk tingkat pendapatan, sedangkan $\alpha$ dan $\beta$ adalah parameter model, sedangkan $\mathrm{z}_{\mathrm{i}}$ adalah random term dengan distribusi standar normal, maka model estimasi yang digunakan dalam penelitian ini secara matematis dapat dituliskan sebagai berikut. 
$\mathrm{wtp}=\beta_{0}+\beta_{1}$ Age $+\beta_{2} \mathrm{Edu}+\beta_{3} \mathrm{Empl}+\beta_{4}$ Gnder $+\beta_{5}$ Inc $+\beta_{6} \mathrm{PL}+\beta_{7} \mathrm{PS}+\mathrm{z}_{\mathrm{i}}$

di mana PS $=\alpha_{0}+\alpha_{1}$ dsick $+\mathrm{z}$ (2), sehingga

$$
\begin{aligned}
& \mathrm{wtp}_{\mathrm{i}}=\beta_{0 i}+\beta_{1 i} \text { age }+\beta_{2 i} \mathrm{edu}+\beta_{3 i} \text { empl }+\beta_{4 i} \text { gnder }+\beta_{5 i} \text { inc }+\beta_{6 i} \mathrm{pl}+\beta_{7 i} \mathrm{PS}+\varepsilon_{\mathrm{i}} \\
& =\beta_{0 i}+\beta_{1} \text { age }+\beta_{2 i} \text { edu }+\beta_{3 i} \text { empl }+\beta_{4 i} \text { gnder }+\beta_{5 i} \text { inc }+\beta_{6 i} \mathrm{pl}+\beta_{7 i}\left(\alpha_{0 i}+\alpha_{1 i}\right. \text { dsick } \\
& \left.+\mathrm{z}_{\mathrm{i}}\right)+\varepsilon_{\mathrm{i}}
\end{aligned}
$$

$$
\begin{aligned}
& =\left(\beta_{0 i}+\gamma_{0 i}\right)+\beta_{1 i} \text { age }+\beta_{2 i} \text { edu }+\beta_{3 i} \text { empl }+\beta_{4 i} \text { gnder }+\beta_{5 i} \text { inc }+\beta_{6 i} \mathrm{pl}+\gamma_{1 i} \text { dsick }+ \\
& \theta_{i}
\end{aligned}
$$

$$
=\delta_{0 \mathrm{i}}+\beta_{1 i} \text { age }+\beta_{2 i} \mathrm{edu}+\beta_{3 i} \mathrm{empl}+\beta_{4 i} \text { gnder }+\beta_{5 i} \text { inc }+\beta_{6 i} \mathrm{pl}+\gamma_{1 i} \mathrm{dsick}+\theta_{i}
$$

Karena WTP tidak dapat diobservasi dalam bidding game maka persamaan (1) di atas tidak dapat diestimasi. Jika $\mathrm{B}_{1}, \ldots, \mathrm{B}_{\mathrm{m}}$ adalah nilai yang membagi range WTP menjadi $\mathrm{m}+1$ kategori, dan $\mathrm{y}_{\mathrm{h}}$ adalah variabel kategori, sehingga

$y_{h}=\ldots\left\{\begin{array}{l}1 \text { jika wtp }<B_{1} \\ 2 \text { jika } B_{1}<w t p<B_{2}\end{array}\right.$

$\mathrm{M}+1$ jika wtp $>\mathrm{B}_{2}$

Jika $\mathrm{i}=1, \ldots, \mathrm{M}+1$, maka dari persamaan (1) akan didapat $\mathrm{y}_{\mathrm{h}}=\mathrm{i}$ jika:

$\mathrm{B}_{\mathrm{i}-1}<\alpha_{0}+\beta_{\mathrm{i}} \mathrm{x}_{\mathrm{h}}+\mathrm{z}_{\mathrm{i}}<\mathrm{B}_{\mathrm{i}}$

$\operatorname{AtauB}_{\mathrm{i}-1}-\alpha_{0}<\beta_{\mathrm{i}} \mathrm{x}_{\mathrm{h}}+\mathrm{z}_{\mathrm{i}}<\mathrm{B}_{\mathrm{i}}-\alpha_{0}$

$\operatorname{Atau}\left(\mathrm{B}_{\mathrm{i}-1}-\alpha_{0}-\beta_{\mathrm{i}} \mathrm{x}_{\mathrm{h}}\right) / \sigma<\left(\mathrm{B}_{\mathrm{i}}-\alpha_{0}-\beta_{\mathrm{i}} \mathrm{x}_{\mathrm{h}}\right) / \sigma$,

Di mana $\sigma$ adalah standar deviasi dari $\mathrm{z}_{\mathrm{i}}$. Diasumsikan $\mathrm{z}_{\mathrm{i}}$ mengikuti distribusi normal standar, maka

$$
\begin{aligned}
\mathrm{P}(\mathrm{y}=\mathrm{i}) & =\mathrm{P}\left(\mathrm{B}_{\mathrm{i}-1}<\mathrm{wtp}<\mathrm{B}_{\mathrm{i}-1}\right) \ldots \ldots \ldots \ldots . . . \\
& =\mathrm{P}\left(\mathrm{u}_{\mathrm{i}-1}-\beta_{\mathrm{i}} \mathrm{x}_{\mathrm{h}}<\mathrm{z}_{\mathrm{i}}<\mathrm{u}_{\mathrm{i}}-\beta_{\mathrm{i}} \mathrm{x}_{\mathrm{h}}\right) \\
& =\mathrm{F}\left(\mathrm{u}_{\mathrm{i}}-\beta_{\mathrm{i}} \mathrm{x}_{\mathrm{h}}\right)-\mathrm{F}\left(\mathrm{u}_{\mathrm{i}-1}-\beta_{\mathrm{i}} \mathrm{x}_{\mathrm{h}}\right)
\end{aligned}
$$

Di mana $u_{i}=B_{i}-\alpha_{0}$ dan $F($.$) adalah fungsi densitas standar normal kumulatif.$ Persamaan (6) adalah persamaan probit yang akan digunakan untuk menjelaskan variasi dalam bidding WTP. Estimasi yang konsisten dengan $\mathrm{u}_{\mathrm{i}}$ dan $\mathrm{x}_{\mathrm{h}}$ adalah maksimum likelihood.

Setelah adanya informasi kondisi kesehatan terkini (persamaan recursive).

$$
\begin{aligned}
& \text { wtpi }=\beta_{0 i}+\beta_{1 \mathrm{i}} \text { Age }+\beta_{2 \mathrm{i}} \mathrm{Edu}+\beta_{3 \mathrm{i}} \text { Empl }+\beta_{4 \mathrm{i}} \text { Gnder }+\beta_{5 \mathrm{i}} \text { Inc }+\beta_{6 \mathrm{i}} \mathrm{PL}+\beta_{7 \mathrm{i}} \mathrm{PS}+\varepsilon_{\mathrm{i}} \\
& \mathrm{PS}_{\mathrm{i}}=\alpha_{0 i}+\alpha_{1 i} \mathrm{dsick}+\alpha_{2 i} \mathrm{GD}+\mathrm{z}_{\mathrm{i}}
\end{aligned}
$$


Masukkan persamaan (15) ke dalam persamaan (16) sehingga

$$
\begin{aligned}
& \mathrm{wtp}_{\mathrm{i}}=\beta_{0 i}+\beta_{1 i} \text { age }+\beta_{2 i} \mathrm{edu}+\beta_{3 i} \mathrm{empl}+\beta_{4 i} \text { gnder }+\beta_{5 i} \text { inc }+\beta_{6 i} \mathrm{pl}+\beta_{7 i} \mathrm{PS}+\varepsilon_{\mathrm{i}} \ldots \text { (17) } \\
& =\beta_{0 i}+\beta_{1 i} \text { age }+\beta_{2 i} \text { edu }+\beta_{3 i} \text { empl }+\beta_{4 i} \text { gnder }+\beta_{5 i} \text { inc }+\beta_{6 i} \mathrm{pl}+\beta_{7 i}\left(\alpha_{0 i}+\alpha_{1 i}\right. \text { dsick } \\
& \left.+\alpha_{2 i} \mathrm{GD}+\mathrm{z}_{\mathrm{i}}\right)+\varepsilon_{\mathrm{i}} \\
& =\beta_{0 i}+\beta_{1 i} \text { age }+\beta_{2 i} \text { edu }+\beta_{3 i} \text { empl }+\beta_{4 i} \text { gnder }+\beta_{5} \text { inc }+\beta_{6 i} \mathrm{pl}+\beta_{7 i} \alpha_{0 i}+ \\
& \beta_{7 i} \alpha_{1 i} \mathrm{dsick}+\beta_{7 i} \alpha_{2 i} \mathrm{GD}+\beta_{7 i} \alpha_{3 i} \mathrm{GD}+\left(\beta_{7 i} \mathrm{z}_{\mathrm{i}}+\varepsilon_{\mathrm{i}}\right) \\
& =\beta_{0 i}+\beta_{1 i} \text { age }+\beta_{2 i} \text { edu }+\beta_{3 i} \text { empl }+\beta_{4 i} \text { gnder }+\beta_{5 i} \text { inc }+\beta_{6 i} \mathrm{pl}+\gamma_{0 i}+\gamma_{1 i} \text { dsick }+ \\
& \gamma_{2 i} \mathrm{MAP}+\theta_{i}
\end{aligned}
$$

\begin{tabular}{|c|c|c|}
\hline Var & Deskripsi Variabel & Nilai \\
\hline Inc & Besarnya pendapatan / bulan & $\begin{array}{l}1 \text { jika } 2 \text { juta } \leq \text { inc }<4 \text { juta Rupiah; } 2 \text { jika } 4 \text { juta } \\
\leq \text { inc }<7 \text { juta Rupiah; } 3 \text { jika pendapatan di atas } \\
7 \text { juta Rupiah }\end{array}$ \\
\hline Age & Usia & Tahun \\
\hline Edu & $\begin{array}{l}\text { Dummy yang menggambarkan tingkat } \\
\text { pendidikan terakhir }\end{array}$ & 1 jika $S 1 ; 2$ jika S2; 3 jika S3 \\
\hline Empl & $\begin{array}{l}\text { Dummy yang menggambarkan status } \\
\text { pekerjaan }\end{array}$ & 1 jika PNS; 0 jika non-PNS \\
\hline PL & Dummy yang menggambarkan pola hidup & 1 jika sehat; 0 jika tidak sehat \\
\hline Gend & Dummy yang menggambarkan jenis kelamin & 1 jika laki-laki; 0 jika peremnpuan \\
\hline PS & $\begin{array}{l}\text { Dummy yang menggambarkan keyakinan } \\
\text { subjektif atas status kesehatan }\end{array}$ & 1 jika sehat; 0 jika tidak sehat \\
\hline GD & Kadar gula dalam darah & 1 jika sehat; 0 jika tidak sehat \\
\hline
\end{tabular}

Berikut ini deskripsi variabel penjelas yang digunakan dalam analisis.

\section{Tabel 1. Deskripsi dan Definisi Operasional Variabel Sosio Demografi yang Digunakan dalam Regresi Probit TSLS}

\section{HASIL PENELITIAN DAN PEMBAHASAN}

Berdasarkan usia, sebagian besar partisipan untuk kedua kelompok berusia antara tiga puluh lima sampai tiga puluh tujuh tahun. Empat puluh enam partisipan kelompok tritmen berada dalam batas usia tersebut, bahkan untuk kelompok kontrol lima puluh persen partisipan juga berada pada batas usia tersebut. Nilai rerata WTP tertinggi kelompok tritmen, baik untuk WTP prior maupun posterior, dimiliki oleh kelompok partisipan yang berusia 46 tahun dengan nilai rerata WTP prior tertinggi sebesar Rp900.000,00 dan nilai rerata WTP posterior sebesar Rp1.250.000,00. Hal menunjukkan bahwa kelompok partisipan usia 46 tahun memiliki keyakinan subjektif bahwa mereka memiliki prevalensi tertinggi relatif terhadap kelompok usia yang lain untuk terjangkit penyakit diabetes mellitus.

Nilai rerata WTP kelompok kontrol untuk WTP prior maupun WTP posterior dimiliki oleh kelompok usia 41 tahun dengan rerata nilai WTP, baik prior dan posterior tertinggi sebesar Rp755.000,00. Artinya bahwa kelompok usia 41 tahun memiliki 
keyakinan subjektif memiliki prevalensi tertinggi relatif dibanding kelompok usia yang lain.

Berdasar tingkat pendidikan, kelompok tritmen terdiri atas delapan orang berpendidikan di bawah S1 (16 persen), delapan orang berpendidikan S1 (16 persen), tiga puluh satu orang berpendidikan S2 (62 persen) dan tiga orang berpendidikan terakhir S3 (6 persen). Sedangkan untuk kelompok kontrol, tujuh belas orang berpendidikan di bawah S1 (34 persen), dua puluh delapan orang berpendidikan S1 (56 persen) dan lima orang berpendidikan S2 (10 persen). Terjadi perubahan nilai WTP untuk semua kelompok pendidikan, atau dengan kata lain belief updating dilakukan oleh semua subjek pada semua level pendidikan. Nilai rerata WTP baik WTP prior maupun posterior dimiliki kelompok pendidikan S1 dengan nilai rerata WTP prior sebesar Rp733.333,3 dan nilai rerata WTP posterior sebesar Rp811.111,1. Kelompok pendidikan ini memiliki keyakinan subjektif bahwa mereka memiliki prevalensi risiko untuk terjangkit penyakit yang tertinggi relatif dibanding kelompok pendidikan yang lain.

Nilai WTP rerata tertinggi pada kelompok kontrol baik untuk WTP1 maupun WTP2 dimiliki oleh kelompok pendidikan S1, yaitu untuk rerata WTP prior sebesar Rp450.689,70 dan rerata WTP posterior sebesar Rp483.448,30. Artinya bahwa kelompok pendidikan pada kelompok kontrol juga memiliki keyakinan subjektif bahwa mereka memiliki prevalensi risiko tertinggi untuk terjangkit penyakit diabetes mellitus relatif dibanding kelompok pendidikan yang lain.

Berdasar tingkat penghasilan, sebagian besar partisipan kedua kelompok berpenghasilan antara dua sampai empat juta, di mana untuk kelompok tritmen berjumlah tiga puluh dua orang (64 persen) dan untuk kelompok kontrol berjumlah empat puluh satu orang ( 82 persen).Hanya tujuh belas ( 34 persen) partisipan tritmen dan sembilan (18 persen) partisipan kontrol yang berpenghasilan antara empat hingga tujuh juta.Sedangkan tidak ada seorang pun partisipan kontrol yang berpenghasilan di atas tujuh juta, sedang kelompok tritmen hanya satu orang ( 2 persen) berpenghasilan di atas tujuh juta per bulan.

Rerata nilai WTP berdasarkan tingkat penghasilan untuk kelompok tritmen, baik WTP prior maupun WTP posterior, dimiliki oleh kelompok pendapatan di atas Rp7.000.000,00. Artinya bahwa kelompok pendapatan tersebut meyakini secara subjektif bahwa memiliki manfaat tertinggi atas asuransi kesehatan relatif dibanding kelompok pendapatan lainnya, disebabkan mereka meyakini bahwa prevalensi risiko mereka untuk terjangkit penyakit akut paling tinggi relatif dibanding kelompok pendapatan yang lain. Untuk kelompok kontrol, nilai rerata WTP tertinggi baik untuk prior maupun posterior didasarkan tingkat pendapatan dimiliki oleh kelompok pendapatan antara Rp2.000.000,00 s.d. Rp4.000.000,00. Kelompok pendapatan ini meyakini secara subjektif bahwa mereka memiliki prevalensi risiko tertinggi untuk 
terjangkit penyakit akut dibanding kelompok pendapatan lainnya. Rerata nilai WTP prior sebesar Rp414.021,70 dan WTP posterior sebesar Rp457.391,30.

Berdasar pemeriksaan kesehatan yang dilakukan terhadap kelompok tritmen diketahui rata-rata kadar gula darah, tiga puluh enam (72 persen) partisipan termasuk dalam kategori normal, lima orang (10 persen) termasuk dalam kategori tinggi dan sembilan orang (18 persen) termasuk dalam kategori sangat tinggi. Subjek dengan kadar gula darah sangat tinggi $(>160 \mathrm{mg} / \mathrm{dl})$ memiliki nilai rerata WTP prior dan WTP posterior belief tertinggi. Partisipan dengan kadar gula darah sangat tinggi meyakini secara subjektif bahwa dengan status kesehatan terkini mereka akan menerima manfaat terbesar dari kepemilikan asuransi kesehatan relatif dibanding kelompok dengan kondisi kesehatan terkini yang lain.

Disebabkan nilai willingness to pay (wtp) pada kedua kelompok mengalami perubahan untuk wtp prior belief dan posterior belief, maka perlu dilakukan uji apakah terdapat perbedaan signifikan pada besarnya perubahan tersebut maka perlu dilakukan uji beda rata-rata. Dengan $\alpha=10 \%$, dapat dikatakan bahwa terdapat perbedaan yang signifikan antara $\mathrm{WTP}_{1}$ kelompok tritmen dan kelompok kontrol. Dengan kata lain, pada kondis $\mathrm{T}=0$ (baseline) nilai WTP kedua kelompok berbeda. Berikutnya juga perlu diuji beda rata-rata nilai $\mathrm{WTP}_{2}$. Dengan $\alpha=10 \%$, dapat dikatakan bahwa terdapat perbedaan yang signifikan antara $\mathrm{WTP}_{2}$ kelompok tritmen dan kelompok kontrol. Kondisi ini membutuhkan pengujian apakah perubahan nilai wtp pada kelompok tritmen benarbenar disebabkan oleh pemeriksaan kadar gula darah. Uji dilakukan dengan uji difference-in-difference (DID). Dengan $\alpha=1 \%$, dapat dikatakan bahwa terdapat perbedaan yang signifikan pada besarnya perubahan WTP kelompok tritmen dan WTP kelompok kontrol $\left(\mathrm{NE} \mathrm{WTP}_{\mathrm{T}} \neq \mathrm{NE} \mathrm{WTP}_{\mathrm{C}}\right)$. Artinya bahwa bahwa benar perubahan WTP pada kelompok tritmen tersebut disebabkan karena tritmen yang diberikan.

Untuk mendukung hasil dari uji DID di atas, dilakukan pengujian dengan melakukan regresi pada model estimasi dengan memasukkan variabel waktu (Time) dan efek netto dari tritmen (net effect). Dari hasil di atas terlihat bahwa efek tritmen sigifikan mempengaruhi nilai WTP maupun keputusan pembelian asuransi kesehatan.Hal ini didasarkan pada hasil regresi di bawah ini bahwa variabel net effect (NE) signifikan mempengaruhi kedua variabel dependen tersebut, sementara variabel waktu (Time) tidak signifikan mempengaruhi kedua variabel dependen tersebut.Artinya bahwa, ceteris paribus, tritmen yang diberikan signifikan berpengaruh terhadap kedua variabel di atas, sebab sepanjang waktu tidak ada perubahan nilai WTP jika tidak ada tritmen atau informasi yang diterima. Dengan kata lain, informasi hasil pemeriksaan kesehatan yang didasarkan pada pemeriksaan kadar gula darah signifikan mempengaruhi cerapan status kesehatan dan WTP asuransi kesehatan pada partisipan tritmen.

Berdasarkan hasil estimasi persamaan willingness to pay pada kelompok kontrol menunjukkan bahwa keyakinan individu atas status kesehatan signifikan dipengaruhi oleh jumlah hari sakit dalam sebulan. Berdasarkan hasil perhitungan marginal effect-nya 
diketahui bahwa jika jumlah hari sakit bertambah satu hari, maka akan menurunkan probabilitas individu untuk meyakini secara subjektif bahwa mereka sehat sebesar 1 persen. Variabel jenis pekerjaan (empl), pendapatan (inc) dan status kesehatan (stat1f) signifikan mempengaruhi besarnya nilai WTP1. Individu yang berprofesi sebagai PNS signifikan memiliki nilai WTP yang lebih tinggi dibanding nilai WTP partisipan nonPNS, ceteris paribus.Dari ketiga variabel yang signifikan mempengaruhi nilai WTP individu tersebut, hanya variabel pendapatan yang signifikan berpengaruh terhadap keputusan pembelian asuransi kesehatan. Dari hasil perhitunganmarginal effect, berawal dari pendapatan Rp2.000.000,00 ketika pendapatan naik Rp1.000.000,00 maka peluang individu untuk membeli asuransi kesehatan naik 46.55 persen.

Pada estimasi status kesehatan 2 ketika bertambah sehari jumlah hari sakit maka estimasi logit atas status kesehatan turun 1.89 , atau berdasarkan jumlah hari sakit terdapat 15 persen partisipan $\left(\approx \mathrm{e}^{-1.887207}\right)$ yang memiliki kemungkinan akan memiliki keyakinan subjektif bahwa mereka tidak sehat. Ketika jumlah hari sakit bertambah satu hari maka peluang seorang individu untuk meyakini bahwa dirinya sehat turun 1 persen.Jika dibandingkan dengan hasil estimasi status kesehatan 1, terjadi perubahan persentase peluang individu yang meyakini tidak sehat. Pada status kesehatan 1 terdapat 11 persen yang meyakini tidak sehat, sementara pada status kesehatan 2 naik menjadi 15 persen. hasil regresi nilai WTP2 dan keputusan pembelian asuransi (Askes2) menunjukkan bahwa variabel jenis pekerjaan, pendapatan (inc) dan status kesehatan 2 (stat2f) signifikan mempengaruhi kedua variabel dependen tersebut. Ketika pendapatan berawal dari Rp2.000.000,00 naik Rp1.000.000,00, ceteris paribus, meningkatkan nilai WTP sebesar Rp258.676,7 dan akan meningkatkan peluang untuk membeli asuransi kesehatan sebesar 42.16 persen. Sedangkan ketika status kesehatan naik sebesar satu unit, ceteris paribus, maka besarnya nilai WTP turun Rp438.045,00 serta menurunkan peluang untuk membeli asuransi kesehatan sebesar 93.41 persen.

Pada kelompok tritmen, berdasarkan jumlah hari sakit, terdapat sekitar 6 persen partisipan $\left(\approx \mathrm{e}^{-2.795656}\right)$ yang berpeluang untuk meyakini bahwa mereka tidak sehat (stat1). Berdasarkan perhitunganmarginal effect, ketika jumlah hari sakit dalam sebulan (dsick) bertambah sehari, maka peluang individu untuk meyakini bahwa mereka sehat akan turun sebesar 11.15 persen. Hasil regresi persamaan wtp menunjukkan bahwa variabel pendapatan (inc) signifikan berpengaruh pada besarnya nilai WTP dan keputusan pembelian asuransi. Ketika pendapatan berawal dari Rp2.000.000,00, ceteris paribus, naik Rp1.000.000,00 maka nilai WTP meningkat Rp349.498,50 dan peluang membeli asuransi naik sebesar 45.60 persen. Ketika status kesehatan individu naik satu unit, maka besarnya nilai WTP turun sebesar Rp177.444,50. Variabel status kesehatan ini tidak signifikan mempengaruhi keputusan individu dalam pembelian asuransi kesehatan, hanya variabel pendapatan yang signifikan. Artinya individu akan membeli premi asuransi kesehatan jika dengan pendapatan yang ada mereka mampu membelinya, tanpa mempertimbangkan status kesehatannya. 
Setelah partisipan menerima tritmen berupa pemeriksaan kadar gula dalam darah, variabel informasi kadar gula darah signifikan mempengaruhi keyakinan subjektif atas tekanan individu atas status kesehatannya, di samping variabel dsick. Jika hasil pemeriksaan gula darah berada pada ambang normal, maka hal ini juga signifikan meningkatkan estimasi logit individu memiliki keyakinan status kesehatan yang baik sebesar 1.80448.Atau dengan kata lain, berdasarkan jumlah hari sakit, terdapat sekitar 2.35 persen partisipan $\left(\approx \mathrm{e}^{-0.856092}\right.$ ) yang berpeluang untuk meyakini bahwa mereka tidak sehat. Sedangkan berdasarkan kondisi gula darah terkini, terdapat 63 persen $\left(\mathrm{e}^{1.840448}\right)$ partisipan yang berpeluang untuk meyakini bahwa mereka sehat. Berdasar hasil perhitungan marginal effect, jika jumlah hari sakit dalam sebulan meningkat satu hari peluang individu untuk meyakini bahwa mereka sehat akan turun sebesar 20.7 persen. Jika hasil pemeriksaan gula darah turun satu satuan maka probabilitas individu untuk meyakini bahwa mereka sehat akan naik 43 persen.

Variabel stat2 berpengaruh signifikan pada Askes2, tetapi tidak signifikan mempengaruhi Askes1. Hal ini mengindikasikan bahwa pemeriksaan kadar gula dalam darah akan mempengaruhi besarnya nilai WTP individu dan keputusan pembelian asuransi kesehatan. Artinya bahwa setelah individu memahami risiko kesehatan yang dimilikinya, selanjutnya mereka akan mempertimbangkan perlu tidaknya melakukan tindakan mitigasi terhadap risiko yang mungkin terjadi. Ketika pendapatan, berawal dari Rp2.000.000,00 naik Rp1.000.000,00, ceteris paribus, maka besarnya nilai WTP naik sebesar Rp233.119,40. Jika status kesehatan naik satu unit akan menurunkan nilai WTP sebesar Rp322.327,00 dan probabilitas membeli asuransi turun sebesar 45,37 persen. Variabel pendapatan tidak signifikan terhadap keputusan berasuransi berdasar posterior belief, tetapi variabel status kesehatan menjadi satu-satunya variabel signifikan terhadap keputusan pembelian asuransi.Hal ini mengindikasikan bahwa, given pendapatan yang dimiliki, ketika status kesehatan memburuk maka individu lebih mungkin membeli asuransi kesehatan.

\section{KESIMPULAN}

Berdasarkan bukti dari eksperimen lab yang dilaksanakan tentang analisis pengaruh informasi kadar gula darah dan probabilitas terjangkitnya penyakit diabetes mellitus terhadap keyakinan subjektif individu atas status kesehatannya dan nilai willingness to pay (WTP) asuransi kesehatan, dapat ditarik kesimpulan seperti tersebut di bawah ini.

1. Partisipan kelompok tritmen dan kelompok kontrol memiliki nilai WTP baseline (WTP1) yang signifikan berbeda. Demikian juga dengan nilai WTP2-nya, terdapat perbedaan yang signifikan antara WTP2 kelompok tritmen dan kelompok kontrol. Hal ini didasarkan pada uji beda rata-rata nilai WTP1 dan WTP2 antara kedua kelompok ini signifikan berbeda. 
2. Dalam Kelompok Kontrol untuk nilai WTP1 dan nilai WTP2 terjadi perubahan, tetapi perubahan tersebut tidak signifikan. Sedangkan untuk kelompok tritmen, nilai WTP1 signifikan berbeda dengan nilai WTP2-nya. Hal ini menunjukkan bahwa seiring waktu, nilai WTP individu dapat berubah. Tetapi dikarenakan pada kelompok tritmen menerima informasi tentang status kesehatan terkini yang didasarkan hasil pemeriksaan kesehatan, kemungkinan perubahan nilai WTP ini sebagai pengaruh dari tritmen yang diterima. Hal ini terbukti dari tidak adanya perbedaan dalam nilai WTP pada kelompok kontrol.

3. Pengujian dengan metode DID (difference-in-difference) menunjukkan bahwa perubahan nilai WTP benar-benar diakibatkan oleh tritmen yang diberikan. Hasil pengujian dengan metode DID ini terdukung oleh hasil pengujian regresi model estimasi dimana variabel net effect (NE) signifikan mempengaruhi nilai WTP premi asuransi kesehatan, sedangkan variabel waktu (Time) tidak signifikan. Hasil ini menunjukkan bahwa tanpa adanya tritmen yang diberikan, perubahan waktu saja tidak dapat secara signifikan mengubah keyakinan subjektif dan nilai WTP individu atas premi asuransi kesehatan. Hanya informasi kadar gula darah terkini yang mampu mengubah kedua variabel tersebut.

4. Selain variabel NE, berdasarkan hasil regresi, beberapa variabel yang signifikan mempengaruhi nilai WTP adalah variabel pendapatan (inc) dan status kesehatan (statf). Pendapatan merupakan faktor kunci yang menentukan besarnya nilai WTP individu atas premi asuransi kesehatan, dengan berawal dari pendapatan sebesar Rp 2.000.000,00, ceteris paribus, semakin tinggi pendapatan akan semakin tinggi nilai WTP, dan semakin meningkatkan peluang individu untuk membeli asuransi kesehatan. Ketika WTP individu lebih besar dari atau sama dengan harga premi yang ditawarkan perusahaan asuransi, maka dapat dipastikan bahwa individu yang bersangkutan membeli asuransi kesehatan. Untuk variabel status kesehatan (statf) merupakan fungsi dari jumlah hari sakit dalam sebulan (dua puluh hari kerja). Banyaknya jumlah hari sakit ini berpengaruh negatif signifikan terhadap status kesehatan. Semakin banyak jumlah hari sakit akan menurunkan peluang individu memiliki keyakinan subjektif bahwa diri mereka sehat. Status kesehatan berpengaruh negatif signifikan terhadap nilai WTP dan keputusan berasuransi. Semakin banyak jumlah hari sakit akan meningkatkan nilai WTP dan peluang berasuransi.

5. Hasil regresi pengaruh variabel-variabel kontrol yang meliputi: usia (age), pendidikan (edu), jenis pekerjaan (empl), jenis kelamin (gnder), pendapatan (inc) dan pola hidup (LS) terhadap nilai WTP asuransi kesehatan dan keputusan pembelian memberikan hasil berbeda pada kelompok tritmen dan kelompok kontrol.

6. Pada kelompok kontrol, pada tahap satu variabel pendapatan, jenis pekerjaan dan status kesehatan signifikan berpengaruh terhadap nilai WTP asuransi (WTP1), tetapi hanya variabel pendapatan yang signifikan berpengaruh terhadap kepemilikan asuransi kesehatan (askes1). Kedua variabel dependen tersebut dipengaruhi positif 
signifikan oleh pendapatan. Individu yang berprofesi sebagai PNS, ceteris paribus, justru memiliki nilai WTP lebih tinggi dibanding non-PNS. Untuk variabel status kesehatan signifikan negatif dipengaruhi oleh jumlah hari sakit dalam sebulan (dua puluh hari kerja). Sedangkan untuk nilai WTP2 dan kepemilikan asuransi 2 (Askes2), keduanya signifikan dipengaruhi oleh pendapatan, jenis pekerjaan dan status kesehatan. Pada estimasi kepemilikan asuransi 1 (Askes1), variabel status kesehatan tidak signifikan berpengaruh. Tetapi pada Askes2, variabel ini signifikan. Hal ini menunjukkan bahwa pada kelompok kontrol terjadi perubahan cerapan risiko atau keyakinan subjektif atas status kesehatan individu, meskipun variabel yang mempengaruhi status kesehatan tidak berubah (stat $1=$ stat $2=f(d s i c k)$, sehingga terjadi perubahan keputusan beberapa individu dalam hal kepemilikan asuransi. Kenyataan ini menunjukkan bahwa adanya variabel uncontrolled menyebabkan individu berubah perilakunya. Tetapi secara keseluruhan, perubahan nilai WTP yang berdampak pada keputusan kepemilikian asuransi kesehatan dalam kelompok kontrol tidak signifikan. Hal ini didasarkan pada uji beda rata-rata nilai WTP asuransi yang telah dilakukan sebelumnya.

7. Dalam kelompok tritmen pada tahap satu, variabel pendapatan dan status kesehatan signifikan berpengaruh pada besarnya nilai WTP1, tetapi untuk keputusan kepemilikan asuransi kesehatan hanya signifikan dipengaruhi oleh variabel pendapatan. Untuk status kesehatan, seperti halnya status kesehatan 1 dan 2 pada kelompok kontrol, signifikan hanya dipengaruhi oleh variabel jumlah hari sakit (dsick). Sementara untuk tahap dua, di mana sebelumnya partisipan kelompok ini menerima tritmen berupa pemeriksaan kadar gula darah, status kesehatan signifikan negatif dipengaruhi oleh jumlah hari sakit dan positif signifikan dipengaruhi oleh hasil pemeriksaan kadar gula dalam darah (GD). Semakin mendekati normal kondisi indikator kesehatan tersebut, ceteris paribus, akan meningkatkan keyakinan subjektif individu atas status kesehatannya.

8. Untuk variabel nilai WTP2 signifikan dipengaruhi oleh pendapatan dan status kesehatan, sedangkan untuk kepemilikan asuransi tahap 2 (Askes2), hanya variabel status kesehatan (stat2) yang signifikan. Artinya bahwa informasi status kesehatan terkini yang diterima partisipan signifikan mengubah cerapan risiko partisipan atas status kesehatannya, sehingga given pendapatan mereka saat ini, partisipan mulai mempertimbangkan tindakan antisipasi terhadap risiko kesehatan, dalam hal ini dengan pembelian asuransi kesehatan.

\section{DAFTAR PUSTAKA}

Ballinger, T. P., Palumbo, M. G., \& Wilcox, N. T. (2003). Precautionary Saving and Social Learning across Generation. The Economic Journal, 113, 920-947. 
Barigozzi, F. (2006). Price vs Quantity in Health Insurance Reimbursement. International Journal of Health Care Finance and Economics, 6(3), 191-213.

Barsky, R. B., Juster, F. T., Kimball, M. S. \& Saphiro, M. D. (1997). Preference Parameters and Behavioral Heterogeneity: An Experimental Approach in the Health and Retirement Study. The Quarterly Journal of Economics, 112(2), 537579.

Connelly, L. B. (2004). Economics and Health Promotion. European Journal Health Economics, 5, 236-242.

Diaconis, P., \& Zabell, S. L. (1982). Updating Subjective Probability. Journal of the American Statistical Association, 77(380), 822-830.

Drycott, S \& Dubbs. A. (1998). Cognitive Dissonance: An Overview of the Literature and Its Integration into Theory and Practice in Clinical Psychology. British Journal of Clinical Psychology, 37(3), 341-153.

Epstein, L. G., \& Zhang. J. (2001). Subjective Probabilities on Subjectively Unambigous Event. Econometrica, 69(2), March, 265-306.

Fishburn, P. C. (1986). The Axioms of Subjective Probability. Statistical Science, 1(3), 335-358.

Friedman, B. (1974). Risk Aversion and The Consumer Choice of Health Insurance Option. The Review of Economics and Statistics, 56(2), 209-214.

Gilovich, T., Griffin. D., \& Kahneman D. (Eds.) (2002). Heuristics and Biases: The Psychology of Intuitive Judgment. Cambridge, UK: Cambridge University Press.

Graftstein, R. (1995). Rasionality as Conditional Expected Utility Maximization. Political Psychology, 6(1), 63-80.

Kahneman, D., Slovic, P., \& Tversky, A. (Eds.) (1982). Judgment Under Uncertainty: Heuristics and Biases. Cambridge, UK: Cambridge University Press.

Karni, E \& Mongin, P. (2000). On the Determination of Subjective Probability by Choices. Management Science, 42(2), 233-248.

Kerssens, J. J., \& Groenewegen, P. P. (2005). Consumer Preferences in Social Health Insurance. The European Journal of Health Economics, 6(1), 8-15

Klibanoff, P., \& Ozdenoren, E. (2007). Subjective Recursive Expected Utility. Economic Theory, 30, 49-87.

Machnes, Y. (2006). The Demand for Privat Health Care under National Health Insurance: The Case of Self-Employed. European Journal of Health Economic, 7, 265-269.

Manski, C. F. (1981). Learning and Decision Making when Subjective Probability Have Subjective Domains. The Annals of Statistics, 9(1), 59-65. 
Steleffson, M., Wang, Z.,\& Klein, W. (2006). Effect Cognitive Dissonance on Intentions to Change Diet and Physical Activity among College Student. American Journal of Health Studies, 21(3/4), 219-227.

Varian, H. R. (1992). Microeconomic Analysis $3^{\text {rd }}$ Edition. USA: W.W. Norton \& Company.

Viscussi, W. K. \& Evans, W. N. (1990). Utility Function that Depend on Health Status: Estimates and Economic Implication. American Economic Review, 80(3), 353374.

Wagstaff, A. (1986). The Demand for Health: Some New Empirical Evidence. Journal Health Economic, 5, 195-233.

Zeckhauser, R. (1970). Medical Insurance: A Case Study of the Trade-off between Risk Spreading and Appropriate Incentive. Journal of Economic Theory, 2, 10-26.

Zweifel, P., \& Breyer, F. (1997). Health Economics. Oxford: Oxford University Press. 